九州大学学術情報リポジトリ

Kyushu University Institutional Repository

\title{
Purification of Extracellular Laccase from Rhizoctonia praticola
}

Rogalski, Jerzy

Department of Biochemistry, Maria Curie-Sklodowska University

Janusz, Grzegorz

Department of Biochemistry, Maria Curie-Sklodowska University

Legiec, Dorota

Department of Biochemistry, Maria Curie-Sklodowska University

Cho, Nam-Seok

Wood and Paper Science, Chungbuk National University

他

https://doi.org/10.5109/19530

出版情報: 九州大学大学院農学研究院紀要. 56 (1)，pp.1-7，2011-02. Faculty of Agriculture， Kyushu University

バージョン :

権利関係 : 


\title{
Purification of Extracellular Laccase from Rhizoctonia praticola
}

\author{
Jerzy ROGALSKI ${ }^{1}$, Grzegorz JANUSZ ${ }^{1}$, Dorota LEGIEC ${ }^{1}$, \\ Nam-Seok $\mathrm{CHO}^{2}$, Soo-Jeong SHIN ${ }^{2}$ and Shoji OHGA* \\ Laboratory of Forest Resources Management, Division of Forest Environmental Sciences, \\ Department of Agro-environmental Sciences, Kyushu University, \\ Sasaguri, Fukuoka 811-2415, Japan \\ (Received October 20, 2010 and accepted November 8, 2010)
}

\begin{abstract}
Rhizoctonia praticola was found to produce large amounts of extracellular laccase when grown aerobically on the optimized Lindenberg and Holm medium in fermenter culture with automatic pH control. The laccase from this source was purified to homogeneity by a rapid procedure, using ion-exchange chromatography, affinity chromatography and chromatofocussing. The enzymes isoforms were recovered with a 38- to 115 -fold increase in specific activity and a yield for lac1 $=38.93 \%$; lac2 $=14.71 \%$ and lac3 $=7.65 \%$. The molecular weight of the purified enzymes proved to be 215,175 and $68 \mathrm{kDa}$ respectively as determined by size-exclusion HPLC. The isoelectric points were between 6.6 and 7.8 , and the carbohydrate content in the purified enzymes was between $6.4-9.7 \%$.
\end{abstract}

\section{INTRODUCTION}

Laccases (benzenediol oxygen oxidoreductases, EC 1.10.3.2) are polyphenol oxidases (PPO) that catalyze the oxidation of various substituted phenolic compounds by using molecular oxygen as the electron acceptor (Thurston, 1994). Phylogenetically, laccases are members of the multi-copper protein family including ascorbate oxidase, ceruloplasmin, ferredoxin, phenoxazinone synthase and bilirubin oxidase (Mayer and Staples, 2002; Nakamura and Go, 2005). Until recently, laccases were only found in eukaryotes (fungi, higher plants, insects) (Mayer and Staples, 2002), but now there is strong evidence for their widespread distribution in prokaryotes and the first crystal structure of a bacterial laccase is already available (Enquita et al., 2003). Fungal laccase (benzenediol:oxygen oxidoreductase, EC 1.10.3.2) is an enzyme secreted into the medium by mycelia of Basidiomycetes, Ascomycetes and Deuteromycetes (Leonowicz et al., 2001).

The enzymes are involved in the pathogenicity, immunity and morphogenesis of organisms and in the metabolic turnover of complex organic substances such as lignin or humic matter. The ability of laccases to act on a wide range of substrates makes them highly useful biocatalysts for various biotechnological applications (Claus, 2004; Sharma et al., 2007). Such applications include the detoxification of industrial effluents as well as use as a tool for medical diagnostics and as a bioremediation agent to clean up herbicides, pesticides and certain explosives in soil. Laccases are also used as cleaning agents for certain water purification systems, as catalysts for the manufacture of anti-cancer drugs, and even as ingredients in cosmetics (Couto and Herrera,

\footnotetext{
1 Department of Biochemistry, Maria Curie-Sklodowska University, 20-031 Lublin, Poland

2 Wood and Paper Science, Chungbuk National University, Cheongju 361-763, Korea

* Corresponding author (E-mail: ohga@forest.kyushu-u.ac.jp)
}

2006). A fascinating character of the direct four-electron reduction of oxygen to water is another important application of laccase in the modified electrode of dioxygen sensing system (Rowiński et al., 2004) and in the cathode compartment of biofuel cells (Shleev et al., 2005; Stoica et al., 2009). In 1979 a fungal source of extracellular laccase was found: Rhizoctonia praticola, which produces this enzyme showing an alkali pH optimum for several substrates (Bollag et al. 1979) as well the laccase from Melanocarpus albomyces (Kiiskinen et al., 2002) in contrast to other laccase producers. This characteristic makes Rhizoctonia praticola laccase a potentially very useful tool in many applications mentioned above.

The goal of the presented work was to isolate and purify the extracellular laccase from the basidium fungus Rhizoctonia praticola and to characterize the enzyme including determination of physicochemical and kinetic properties.

\section{MATERIALS AND METHODS}

\section{Strain and culture conditions}

Rhizoctonia praticola 93a was obtained from the culture collection of the Pennsylvania University, USA. The fungus was maintained in $2 \%(\mathrm{w} / \mathrm{v})$ malt agar slants. As an inoculum, pieces of agar were grown in the Lindenberg and Holm (Lindeberg and Holm, 1952) medium in non-agitated conical flasks for 7 days at $28^{\circ} \mathrm{C}$. The mycelial mats were subsequently collected and homogenized in a Waring blender. After inoculation with $2.5 \%(\mathrm{v} / \mathrm{v})$ crumbled fungal mats, the cultures were run at $26^{\circ} \mathrm{C}$ in $100 \mathrm{ml}$ wide-mouth Erlenmeyer flask (each of them containing $40 \mathrm{ml}$ of culture medium) placed on a rotary shaker (180 rpm).

The fermentor scale cultivation was performed at $28^{\circ} \mathrm{C}$ in a 2.51 Bioflo III (New Brunswick; Edison, NJ, USA) fermentor containing 21 of the sterilized Lindenberg and Holm medium (Lindeberg and Holm, 1952) optimized as in Janusz et al. (2006) at $121^{\circ} \mathrm{C}$ by $30 \mathrm{~min}$. The fermentor was inoculated with crumbled fungal mats 
(10\% of total volume), aerated at $1 \mathrm{l}$ air per minute and stirred at $300 \mathrm{rpm}$. Antifoam B emulsion (Sigma, St. Louis, USA) was occasionally added to the fermentor cultures to break the foam. The $\mathrm{pH}$ change was achieved by adding $5 \%$ ammonia or phosphoric acid. The stabilization of $\mathrm{pH}$ on the level of 8.0 on the second day and adding of $5 \mu \mathrm{M}$ cooper ions dose before inoculation were the most convenient for maximalisation of laccase activity. The obtained laccase level in culture liquid was (about 4,000 nkat/l) as in Janusz et al. (2006).

\section{Enzyme purification}

The after culture liquid was centrifuged at $10000 \times \mathrm{g}$ on K6 15 (SIGMA, Osterode am Harz, Germany) centrifuge for $10 \mathrm{~min}$. The supernatant was concentrated 10 times on the ultrafiltration system Pellicon 2 Mini holder (Millipore, Bedford, USA) with Ultracel mini cartridge (10 kDa cut off) and used as the source of crude enzyme. Chromatography was performed using a chromatographic Econo-System (Bio-Rad, Richmond, USA). The enzyme solution was purified on a vanillyl-CPG carrier synthesised as in Rogalski et al. (1990) and equilibrated on the column $(1.5 \times 10 \mathrm{~cm})$ with $0.01 \mathrm{M}$ Mc Ilvaine buffer $(\mathrm{pH}$ 8.0). The proteins not bounded to the column were eluted by the same buffer, whereas bounded ones by applying $0.7 \mathrm{M}$ ammonium sulphate. Fractions showing laccase activities were pooled and applied to a DEAESepharose column $(2.5 \times 15 \mathrm{~cm})$ pre-equilibrated with 20 mM Tris-HCl buffer ( $\mathrm{pH}$ 6.5). The proteins adsorbed on the column were eluted with a 0-0.5 M linear gradient of $\mathrm{NaCl}$ at the flow rate of $1 \mathrm{ml} / \mathrm{min}$. Active laccase fractions (obtained after DEAE-Sepharose) were next chromatofocused on PBE-94 ion exchanger packed in chromatography column $(1 \times 20 \mathrm{~cm})$ equilibrated with $250 \mathrm{ml}$ of a $0.025 \mathrm{M}$ TRIS/acetate buffer ( $\mathrm{pH}$ 8.35). A sample showing laccase activity $(5 \mathrm{ml})$ was injected onto the column, and the enzyme was desorbed by elution with $200 \mathrm{ml}$ of Polybuffers 96 and 74 (25/75; v/v), stabilizing at $\mathrm{pH} 4.5$ by acetate acid, at the flow rate of $0.5 \mathrm{ml} / \mathrm{min}$. The active fractions were pooled, and the purified enzyme solutions were used for further kinetic experiments.

\section{Laccase and other assay}

The activity of the laccase was determined by following the oxidation of $0.025 \mathrm{mM}$ syringaldazine in $0.1 \mathrm{M}$ citrate-phosphate buffer at $\mathrm{pH} 5.0$ (Leonowicz and Grzywnowicz, 1981) by photometry at $\lambda=525 \mathrm{~nm}\left(\varepsilon_{525}=\right.$ $6.5 \cdot 10^{4} \mathrm{M}^{-1} \mathrm{~cm}^{-1}$ at $\left.25^{\circ} \mathrm{C}\right)$. The activity was expressed in nkat per liter. The protein content was determined with bovine albumin as a standard (Bradford, 1976). The carbohydrate content in the purified laccases were determined by the method of Dubois et al. (1956) using glucose as a standard. The mean standard error in protein determination was $\pm 4.8 \times 10^{-3} \mathrm{mg}$ and ranged from \pm 5.7 $\times 10^{-5}$ to $\pm 9.1 \times 10^{-3}$. For the cooper concentration determination in laccase isoforms the homogenic isoforms of laccase was concentrated $(110 \mu \mathrm{g} / \mathrm{ml})$ and dialyzed against deionized water (Milli Q) by ultrafiltration on centricon YM10 filters (Millipore, Billeria, Mass, USA). The copper content was determined by GR atomic absorp- tion spectroscopy on SpectrAA-880Z with the Zeeman background correction system (Varian, Mulgrave, Australia). Optical absorption spectra were recorded at $25^{\circ} \mathrm{C}$ on a UV 160A spectrophotometer (Shimadzu; Tokyo, Japan) connected to IBM-PC computer with PC160A software and equipped with a TCC controller thermostat cuvette holder in $1 \mathrm{~cm}$ quartz cuvette.

Molecular weight determination of purified laccase isoforms was obtained by the injecting them onto the Protein-Pack 300 SW (10 $\mu$ m; Millipore-Waters, Milford, MA, USA) column connected with Shimadzu HPLC system composed of LC-9A chromatography pump, the SPD-M6A diode array detector and the model 7125 sampling valve (Rheodyne, Berkeley, CA, USA) with $100 \mu \mathrm{l}$ loop. The mobile phase $0.1 \mathrm{M}$ acetate buffer ( $\mathrm{pH}$ 5.0) was run at the flow rate of $0.5 \mathrm{ml} / \mathrm{min}$. The column was calibrated by the linear least square method employing Quattro Pro software (Borland, Qupertino, USA) on IBM PC using the MS II Gel-filtration standard set (Serva, Heidelberg, Germany). The hydrolysis of laccase glycosic compounds was made according to Niku-Paavola et al. (1988). The $0.45 \mathrm{ml}$ samples (0.2 $\mathrm{mg}$ protein) were mixed with $50 \mu \mathrm{l} 10 \% \mathrm{SDS}$ in $100{ }^{\circ} \mathrm{C}$ by $5 \mathrm{~min}$. Next the $50 \mu \mathrm{l}$ Triton X-100 and $5 \mu \mathrm{l}$ N-glucosidase F (Calbiochem, San Diego, CA, USA) was added and the mixture was incubated for $48 \mathrm{hrs}$ at $37^{\circ} \mathrm{C}$. The obtained hydrolysates were analysed by Shimadzu HPLC vp system composed of LC 10AD vp pump, refractive index detector, SLC$10 \mathrm{~A} v p$ system controller, CTO-10A vp column oven and the model 7725i sampling valve (Rheodyne, Berkeley, $\mathrm{CA}$, USA) with $20 \mu \mathrm{l}$ loop on Kromosil- $\mathrm{NH}_{2}$ column $(0.4 \times 25 \mathrm{~cm} ; 10 \mu \mathrm{m}$; Phenomenex $)$ at $25^{\circ} \mathrm{C}$. The mobile phase (a mixture of acetonitrile and water in the ratio $72: 28 \mathrm{v} / \mathrm{v}$ ) was run at the flow rate of $1 \mathrm{ml} / \mathrm{min}$. For the standardization of this column saccharide standard Sugar and Sugaralcohole for chromatography A and B (Merck, Darmstadt, Germany) was used. The glucoronic acid as well as $\mathrm{N}$-acetylglucosamine was quantified by the same HPLC system on Rezex ROA-org acid column ( $8 \mu \mathrm{m}$, $300 \times 7.8 \mathrm{~mm}$; Phenomenex). The mobile phase in the case of uronic acids was $0.005 \mathrm{M} \mathrm{H}_{2} \mathrm{SO}_{4}$ (in Milli Q water) run at $0.5 \mathrm{ml} / \mathrm{min}$ at $55^{\circ} \mathrm{C}$ and for $\mathrm{N}$-acetylglucosamines $1 \%$ phosphoric acid (in Milli Q water) run at $0.6 \mathrm{ml} / \mathrm{min}$ at $25^{\circ} \mathrm{C}$.

\section{Kinetic constants}

The reaction rate was determined at five different substrate (2,6-DMP, syringaldazine, guaiacol, veratric acid and ferulic acid) concentration in the range of 0.01 to $10 \mathrm{mM}$. All assays were performed in triplicate. The kinetic constants $\left(\mathrm{K}_{\mathrm{m}}\right.$, and $\left.\mathrm{V}_{\max }\right)$ for purified laccase isosymes were calculated on an IBM PC employing Wilman 4 (1985) software (M.S.U., USA) using a Clark oxygen electrode (Rank, Cambridge, Great Britain) provided with a linear TZ 4100 recorder (Rogalski et al., 1990).

\section{Chemicals}

4-hydroxy-3,5-dimethoxybenzaldehyde azine (syringaldazine) and 2,6-dimethoxyphenol (DMP) were obtained from Aldich (Steinheim, Germeny) whereas 
3,4-dimethoxybenzoic acid (veratric acid), 3-methoxy, 4-hydroxy cynammic acid (ferulic acid) and 3-hydroxy, 4-methoxybenzene (guaiacol) from Sigma (St. Louis, USA).

\section{RESULTS AND DISCUSSION}

\section{Purification of laccase}

The after-culture liquid from the fermentor after centrifugation at $10000 \times \mathrm{g}$ was concentrated by ultrafiltration on PELICON 2 unit (10 kDa cut off) and loaded onto a vanillyl-CPG column (Fig. 1). The carrier showed the optimum for sorption of $R$. praticola laccase on vanillylCPG at pH 8.0. After eluting the non-adsorbed proteins, further elution was done by applying $0.7 \mathrm{M}$ ammonium sulphate. All the laccase activities were bound to the column, and eluted as one peak. The purification effect of this step was low, as compared to the following ones (Table 1). The enzyme solution obtained in the previous step was applied to a DEAE-Sepharose column (Fig. 2).

After eluting the non-adsorbed proteins, further elution was done by linear gradient from 0 to $0.5 \mathrm{M}$ sodium chloride solution in the same buffer. The laccase activi- ties were eluted as two peaks (first $0 \mathrm{M}$ and second at $0.1-0.2 \mathrm{M} \mathrm{NaCl}$ ). This step resulted in a nearly 29 and 17-fold purification of the enzymes with a recovery 47 and 28\% respectively (Table 1 ). The active fractions of all laccase forms were pooled respectively and further fractionated by chromatofocusing on Polybuffer exchanger PBE 94. The chromatographic pattern are depicted in Fig. 3. Fraction lac I was further purified giving one form lac I with the isoelectric points at 6.75 . This isoform was purified 115-fold with the recovery of $39 \%$. Fraction lac II was divided into two laccase forms (lac Ila and lac IIb) with the isoelectric points at 7.85 and 6.60. These isoforms were purified 57 and 38-fold with the recovery of 14.7 and $7.65 \%$ respectively. The obtained isoelectric points indicate that they differ from the so-called "acidic laccases" as obtained from Coriolus hirsutus, Coriolisimus fulvocinerea, Coriolus zonatus and Cerrena maxima (Smirnov et al., 2001). Bollag et al. (1979) obtained only one form of laccase Rhizoctonia praticola with similar recovery. Similar pI points were determined for laccase from Rhizoctonia solani: 7.5; 7.5; 5.0 (Wahleithner et al., 1996). The isoelectric point of bacterial laccases differs more signifi-

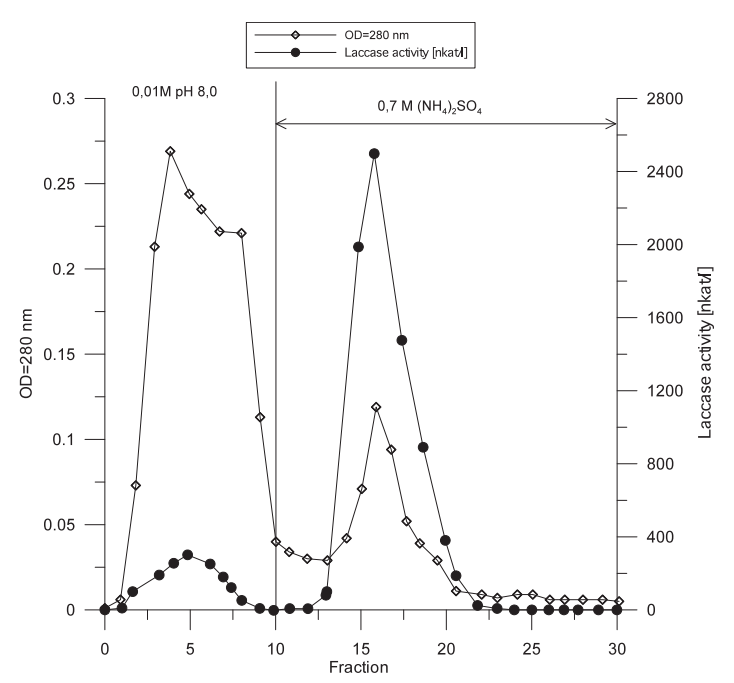

Fig. 1. Chromatography of crude Rhizoctonia praticola laccase on vanillyl-CPG.

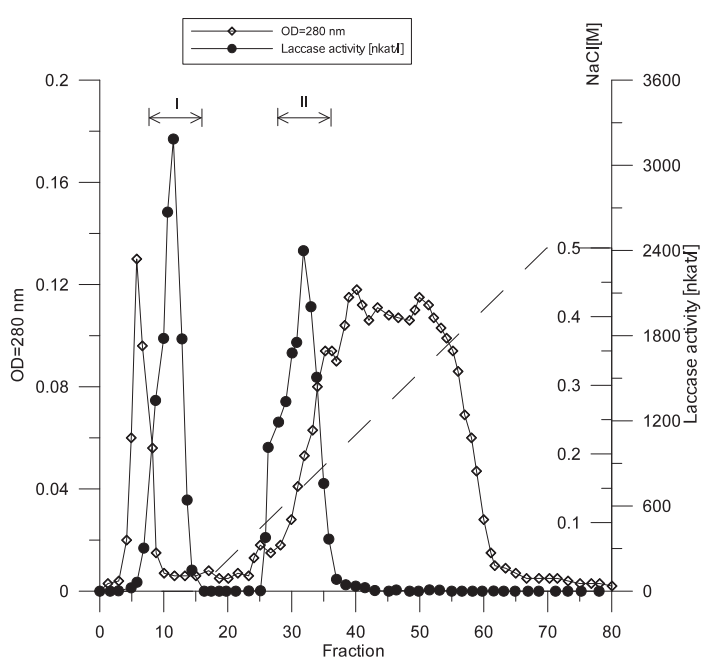

Fig. 2. Chromatography on DEAE-Sepharose of partially purified post vanillyl-CPG laccase.

Table 1. Summary of laccase purification from Rhizoctonia praticola

\begin{tabular}{|c|c|c|c|c|}
\hline Purification step & $\begin{array}{l}\text { Total protein } \\
\text { (mg) }\end{array}$ & $\begin{array}{c}\text { Specific activity } \\
\text { (nkat/mg) }\end{array}$ & $\begin{array}{l}\text { Purification } \\
\text { (fold) }\end{array}$ & $\begin{array}{l}\text { Yield } \\
(\%)\end{array}$ \\
\hline Crude after culture fluid & 277.2 & 18,000 & 1.00 & 100 \\
\hline Ultrafiltration YM-10 & 222.9 & 20,520 & 1.14 & 92 \\
\hline Vanilin-CPG & 57.6 & 69,480 & 3.86 & 80.2 \\
\hline DEAE-Sepharose (fast flow) (fraction II) & 1.40 & 313,920 & 17.4 & 28.5 \\
\hline PBE-94 fraction-lacIIa (pI=7.85) & 0.72 & $1,022,040$ & 56.8 & 14.7 \\
\hline PBE-94 fraction-lac $\Pi b(\mathrm{pI}=6.60)$ & 0.55 & 692,280 & 38.5 & 7.7 \\
\hline
\end{tabular}



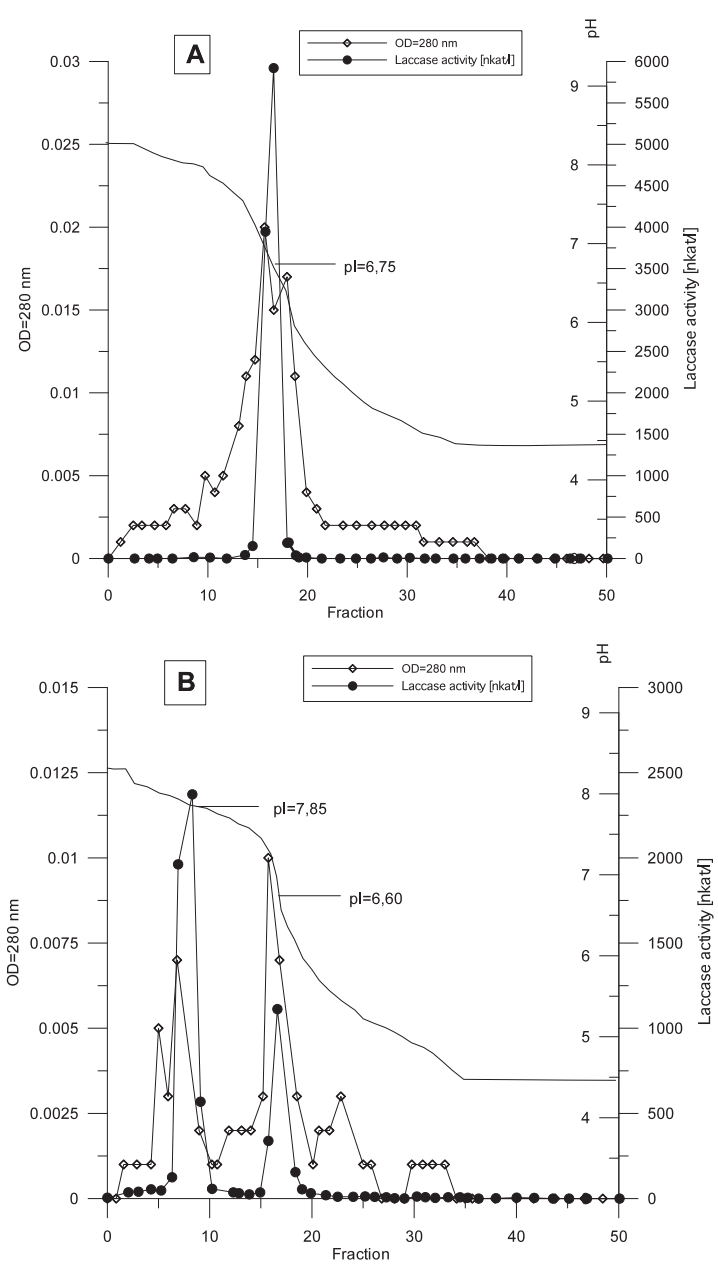

Fig. 3. Chromatofocusing pattern for fraction I (A), fraction II (B) of DEAE-Sepharose purified laccases. cantly in ranges $\mathrm{pI}=5.6$ for laccase from Streptomyces cyaneus (Arias et al., 2003) to $\mathrm{pI}=7.7$ for the one from Bacillus subtilis (Martins et al., 2002).

\section{Physico-chemical and kinetic characterization of laccases}

The purified laccase isoforms showed a high level of specific activity (from 300 to over $2000 \mu \mathrm{kat} / \mathrm{mg}$ protein), which were about 2 times as previously reported in (Bollag et al., 1979) although the condition of determining activity was in above paper different (DMP as a substrate). Homogeneity of the laccase fractions were examined and confirmed by size exclusion HPLC, where the final purified enzymatic preparations appeared as a single protein peak. The molecular weight was determined to be (for lac I = 215; lac Ia = 175; lac Ib = $68 \mathrm{kDa}$ ) presented in Table 2. It was proved several times that laccase may appear as monomer but as dimer, trimer or even oligomer as well (D'Annibale et al., 1996; Wahleithner et al., 1996; Min et al., 2001).

Wahleithner et al., (1996) characterized three of four laccases from Rhizoctonia solani as dimeric. These results may suggest that probably lac I is trimeric and lac II is dimeric in Rhizoctonia praticola. Bollag et al. (1979) determined molecular weight of single form of laccase from Rhizoctonia praticola as $78 \mathrm{kDa}$, which would be similar to our monomer form of lac IIb. Therefore, the obtained molecular weights of purified laccases forms were very similar to the molecular weights of most other fungal laccases, which have been found to be between $60 \mathrm{kDa}$ and $90 \mathrm{kDa}$ (Yaropolov et al., 1994; Smiths and Thurston, 1997; Xu et al., 1999).

The carbohydrate content in the purified enzymes varied from 6.4 to $9.7 \%$, indicating that they are a typical

Table 2. Characteristics of the purified laccases from Rhizoctonia praticola

\begin{tabular}{|c|c|c|c|c|c|}
\hline & & & LacI & LacIIa & LacIIb \\
\hline \multicolumn{3}{|c|}{ Isoelectric point (pI) } & $6.75 \pm 0.14$ & $7.85 \pm 0.20$ & $6.60 \pm 0.18$ \\
\hline \multicolumn{3}{|c|}{ Molecular weight $(\mathrm{kDa})^{\mathrm{a}}$} & $215 \pm 7.9$ & $175 \pm 9.8$ & $68.7 \pm 2.3$ \\
\hline \multicolumn{3}{|c|}{ Carbohydrate content (\%) } & $6.40 \pm 0.54$ & $9.70 \pm 0.70$ & $6.93 \pm 0.60$ \\
\hline \multirow{10}{*}{ 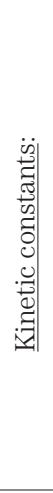 } & \multirow{2}{*}{ (for 2,6-DMP) } & $\mathrm{K}_{\mathrm{m}}(\mathrm{mM})$ & $0.017 \pm 0,004$ & $0.012 \pm 0.004$ & $0.013 \pm 0.003$ \\
\hline & & $\mathrm{V}_{\max }\left(\mu \mathrm{M} \mathrm{O}_{2} / \min \right)$ & $2.055 \pm 0.061$ & $3.183 \pm 0.150$ & $2.859 \pm 0.073$ \\
\hline & \multirow{2}{*}{ (for guaiacol) } & $\mathrm{K}_{\mathrm{m}}(\mathrm{mM})$ & $2.861 \pm 0.064$ & $0.181 \pm 0.015$ & $0.479 \pm 0.063$ \\
\hline & & $\mathrm{V}_{\max }\left(\mu \mathrm{M} \mathrm{O}_{2} / \min \right)$ & $1.956 \pm 0.165$ & $1.136 \pm 0.016$ & $1.797 \pm 0.064$ \\
\hline & \multirow{2}{*}{ (for ferulic acid) } & $\mathrm{K}_{\mathrm{m}}(\mathrm{mM})$ & $0.385 \pm 0.041$ & $3.396 \pm 0.088$ & $7.399 \pm 0.095$ \\
\hline & & $\mathrm{V}_{\max }\left(\mu \mathrm{M} \mathrm{O}_{2} / \min \right)$ & $1.754 \pm 0.037$ & $6.664 \pm 0.748$ & $7.202 \pm 0.539$ \\
\hline & \multirow{2}{*}{ (for veratric acid) } & $\mathrm{K}_{\mathrm{m}}(\mathrm{mM})$ & $-^{\mathrm{b}}$ & $-{ }^{\mathrm{b}}$ & $-{ }^{\mathrm{b}}$ \\
\hline & & $\mathrm{V}_{\max }\left(\mu \mathrm{M} \mathrm{O}_{2} / \min \right)$ & $0.00 \pm 0.00$ & $0.00 \pm 0.00$ & $0.00 \pm 0.00$ \\
\hline & \multirow{2}{*}{ (for syringaldazine) } & $\mathrm{K}_{\mathrm{m}}(\mathrm{mM})$ & $0.673 \pm 0.024$ & $0.235 \pm 0.042$ & $1.159 \pm 0.081$ \\
\hline & & $\mathrm{V}_{\max }\left(\mu \mathrm{M} \mathrm{O}_{2} / \mathrm{min}\right)$ & $4.660 \pm 0.094$ & $5.598 \pm 0.337$ & $14.975 \pm 0.787$ \\
\hline \multicolumn{3}{|c|}{ Cooper ions content (mol/mol) } & $3.23 \pm 0.28$ & $3.35 \pm 0.31$ & $3.26 \pm 0.30$ \\
\hline \multicolumn{3}{|c|}{ Optimum pH } & 7.4 & 7.4 & 7.4 \\
\hline \multicolumn{3}{|c|}{ Optimum temperature $\left({ }^{\circ} \mathrm{C}\right)$} & 60.0 & 60.0 & 60.0 \\
\hline
\end{tabular}

a - estimated by high-performance gel filtration

${ }^{\mathrm{b}}$ - activity was detected only at the highest substrate concentration, and therefore, a $\mathrm{K}_{\mathrm{m}}$ could not be determined 

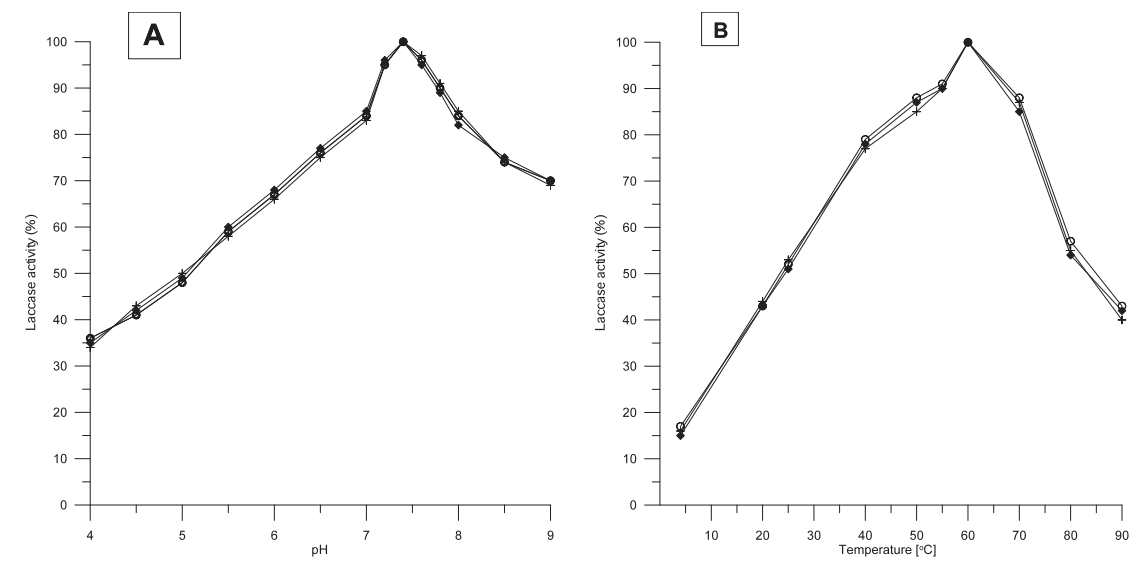

Fig. 4. Effect of $\mathrm{pH}(\mathrm{A})$ and temperature (B) on activity of Rhizoctonia praticola laccases. $(\bigcirc \mathrm{lac}$ I; + lac Ia; $\bullet$ lac Ilb)

glycoprotein. Waihleithner et al. (1996) determined glycosylation content in Rhizoctonia solani laccase from 10 to $20 \%$, but these forms were expressed in Aspergillus oryzeae, which may possess tendency to hyperglycosylate heterogically expressed laccases. Biochemically, laccase is a glycosylated protein monomers or homodimers generally with a lesser count of saccharide compounds (10-25\%) in fungi than plant enzymes (Rogalski and Leonowicz, 2004). In the case of white rot fungi such as Coriolus hirsutus, Coriolus zonatus and Cerrena maxima, these value varied from 10-13\%. Laccase from Coriolisimus fulvocinerea showed atypical carbohydrate contents (32\%) for fungal enzymes (Smirnov et al., 2001). In some species (Schinus molle and Botrytis cinerea) glycosylation of laccase may reach even from 60 to 80\% (Zouari et al., 1985; Bar-Nun et al., 1985).

Thus the Rhizoctonia praticola enzymes were glycoproteins comprising monosaccharides such as mannose, arabinose, fucose, xylose, glucose, and $\mathrm{N}$-acetylglycosamine, glucuronic and sialic acid residues (Table 3). Mannose is a predominant sugar in R. praticola laccase isoforms as well as in other ones (KoroljovaSkorobogat'ko et al., 1998; Giardina et al., 1999; Dedeyan et al., 2000). Glycosylation of laccase is presumed to protect enzyme from proteolysis and thermal degradation (Li et al., 1999). The effect of $\mathrm{pH}$ and temperature on the activity and stability of $R$. praticola laccase iso-

Table3. Sugar content in the purified laccases from Rhizoctonia praticola

\begin{tabular}{lccc}
\hline \multicolumn{1}{c}{ Laccase } & Lac I & Lac Ia & Lac Ib \\
\hline Mannose [mol\%] & 61.12 & 81.56 & 76.37 \\
N-acetyloglucosamine [mol\%] & 9.43 & 11.61 & 9.80 \\
Glucose [mol\%] & - & 6.27 & - \\
Glucuronic acid [mol\%] & 0.08 & 0.56 & 0.27 \\
Sialic acid [mol\%] & - & - & 5.20 \\
Fucose [mol\%] & - & - & 8.36 \\
Arabinose [mol\%] & 29.37 & - & - \\
\hline
\end{tabular}

forms are illustrated in Fig. 4. The optimum $\mathrm{pH}$ for all above forms was 7.4. The effect of temperature on laccasse forms activities were investigated over the range of $4-90^{\circ} \mathrm{C}$. As it is evident from the curves, the optimal temperature for them were $60{ }^{\circ} \mathrm{C}$.

Laccases share the arrangement of the catalytic sites and the catalytic mechanisms with other blue multicopper oxidases. The enzyme contains four copper ions classified as a T1 (one copper), T2 (one copper), and T3 (two coppers) sites in accordance with their spectroscopic characteristics (Solomon et al., 1996). An electron from the substrate is transferred to the T1 site, the primary electron acceptor of the enzyme, which is then transferred through an intramolecular electron transfer (IET) mechanism via a Cys-2His bridge to the T2/T3 cluster, where $\mathrm{O}_{2}$ is reduced to $\mathrm{H}_{2} \mathrm{O}$ (Solomon et al., 1996). It is common to determine cooper content for the newly purified laccase isosymes. The cooper content of the purified laccase was determined by AAS method,

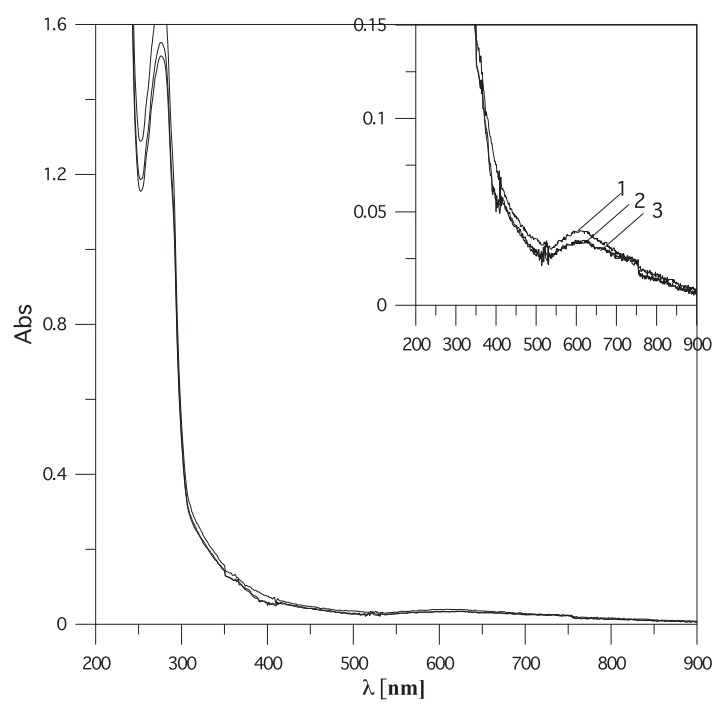

Fig. 5. Absorption spectrum of laccase isoforms from Rhizoctonia praticola $(0.9 \mathrm{mg} / \mathrm{ml}$ in $0.1 \mathrm{M}$ McIlvaine buffer, $\mathrm{pH}$ 5.5) in room temperature (1- lac I; 2- lac Ia; 3- lac IIb). 
which measured in all cases about 3.26-3.35 $\pm 0.28-0.31$ cooper ions per laccase molecule (Table 2). The absorption of homogenic laccases isoforms solutions showed no heme band around $400 \mathrm{~nm}$. There were a small feature around $300 \mathrm{~nm}$, which is known as the ligand to cooper charge transfer type 3 site (Fig. 5). The blue band of these laccases shows an adsorption maximum at $610 \mathrm{~nm}$ with the extinction coefficient of $3,540 \mathrm{M}^{-1} \mathrm{~cm}^{-1}$. These results are very good correlated with those obtained for other blue laccases (Kim et al., 2002).

The $\mathrm{K}_{\mathrm{m}}$ and $\mathrm{V}_{\max }$ values for five various substrates are presented in Table 2 . In the case of veratric acid the purified isosymes did not show affinity to this substrate. It is clear that these enzymes can not belong to the class of yellow laccases because only these kinds of the enzymes can oxidase the veratric acid (Leontievsky et al., 1997). The affinities of laccase forms are different for each substrate. The best substrate for all isoforms was 2,6-DMP. Lac Ila had the highest affinity to this substrate, in the case of lac $\mathrm{Ib}$ the affinity was slightly lower and in the case of lac I - about 50\% lower. The affinities to syringaldazine for lac Ila were also highest in relation to the lac Ilb and lac I where this value was about 6 and 3 times lower respectively. Lac IIa had the highest affinity to guaiacol the affinity of forms lac IIb was about 50\% lower, and lac I - over 10-times lower. The ferulic acid was the best substrate for lac I, in the case of lac Ila the affinity was about 10 times and for lac $\mathrm{Il} b 20$ times lower.

In summary, the laccase isoforms derived from $R$. praticola had some interesting properties which can be used in some technical application e.g. in construction of biofuel cell or biosensors.

\section{ACKNOWLEDGEMENT}

This work was financially supported in part by the research program BS/UMCS and BW/UMCS.

\section{REFERENCES}

Arias, E. M., M. Arenas, J. Rodríguez, J. Soliveri, A. S. Ball and M. Hernández 2003 Kraft pulp biobleaching and mediated oxidation of a nonphenolic substrate by laccase from Streptomyces cyaneus CECT 3335. Appl. Environ. Microbiol., 69: $1953-1958$

Bar-Nun, N. A. M. Mayer and N. Sharon 1981 Properties of laccase in Schinus molle. Phytochem. 20: 407-408

Bollag, J. M. and A. Leonowicz 1984 Comparative studies of extracellular fungal laccases. Appl. Environ. Microbiol., 14: 849-854

Bollag, J. M., R. D. Sjoblad and S. Y. Liu 1979 Characterisation of an enzyme from Rhizoctonia praticola which polymerizes phenolic compounds. Can. J. Microbiol., 25: 229-233

Bradford, M. M. 1976 A rapid and sensitive method for the quantitation of microgram quantities of protein utilizing the principle of protein-dye binding. Anal. Biochem., 72: 248-254

Casella, L., M. Gullotti, E. Monzani, L. Santagostini, G. Zoppellaro and T. Sakurai 2006 Enzymatic and spectroscopic studies on the activation or inhibition effects by substituted phenolic compounds in the oxidation of aryldiamines and catechols catalyzed by Rhus vernicifera laccase. J. Inorg. Biochem. 100: $2127-2139$

Claus, H. 2004 Laccases: structure, reactions, distribution. Micron., 35: 93-96
D'Annibale, A., D. Celletti, M. Felici, E. Di Mattia and G. Sermanni 1996 Substrate specificity of laccase from Lentinus edodes. Acta Biotechnol., 16: 257-270

Dedeyan, B., A. Klonowska, S. Tagger, T. Tron, G. Lacazio, G. Gil and J. Le Petit 2000 Biochemical and molecular characterisation of a laccase from Marasmius quercophilus. Appl. Environ. Microbiol., 66: 925-929

Dubois, M., K. A. Gilles, J. K. Hamilton, P. A. Robers and F. Smith 1956 Colometric method for determination of sugar and related substances. Anal. Chem., 28: 350-356

Enguita, F. J., L. O. Martins, A. O. Henriques and M. A. Carrondo 2003 Crystal Structure of a Bacterial Endospore Coat Component. A laccase with enhanced thermostability properties. J. Biol. Chem., 278: 19416-19425

Giardina, P., G. Palmieri, A. Scaloni, B. Fontanella, V. Faraco, G. Cennamo and G. Sannia 1999 Protein and gene structure of a blue laccase from Pleurotus ostreatus. Biochem. J., 341: $655-663$

Hakulinen. N., K. Kruus, A. Koivula and J. Rouvinen 2006 A crystallographic and spectroscopic study on the effect of $\mathrm{X}$-ray radiation on the crystal structure of Melanocarpus albomyces laccase. Biochem. Biophysic Res. Commun., 350: 929-934

Harald, C. 2004 Laccases: structure, reactions, distribution. Micron, 35: 93-96

Janusz, G., J. Rogalski, M. Barwińska and J. Szczodrak 2006 Effects of culture conditions on production of extracellular laccase by Rhizoctonia praticola. Polish J. Microbiol., 55: 309-319

Jeffries, T. W., S. Choi and T. K. Kirk 1981 Nutritional regulation of lignin degradation by Phanerochaete chrysosporium. Appl. Environ. Microbiol., 42: 290-296

Keyser, P., T. K. Kirk and J. G. Zeikus 1978 Ligninolytic enzyme system of Phanerochaete chrysosporium synthesized in the absence of lignin in response to nitrogen starvation. J. Bacteriol., 135: 790-797

Kiiskinen, L. L., L. Viikari and K. Kraus 2002 Purification and characterisation of a novel laccase from the ascomycete Melanocarpus albomyces. Appl. Microbiol. Biotechnol., 59 : 198-204

Kim, Y., N. S. Cho, T. J. Eom and W. Shin 2002 Purification and characterization of a laccase from Cerrena unicolor and its reactivity in lignin degradation. Bull. Korean Chem. Soc., 23: $985-989$

Koroljova-Skorobogat'ko, O. V., E. V. Stepanova, V. P. Gavrilova, O. V. Morozova, N. V. Lubimova, A. N. Dzchafarova, A. I. Jaropolov and A. Makower 1998 Purification and characterization of the constitutive form of laccase from basidiomycete Coriolus hirsutus and effects of inducers on laccase synthesis. Biotechnol. Appl. Biochem., 28: 47-54

Leonowicz, A. and K. Grzywnowicz 1981 Quantitative estimation of laccase forms in some white-rot fungi using syringaldazine as a substrate. Enzyme Microbiol. Technol., 3: 55-58

Leonowicz, A., N. S. Cho, J. Luterek, A. Wilkolazka, M. WojtasWasilewska, A. Matuszewska, M. Hofrichter, D. Wesenberg and J. Rogalski 2001 Fungal laccase: properties and activity on lignin. J. Basic Microbiol. 41: 185-227

Leontievsky, A., N. Myasoedova, N. Pozdnyakova and L. Golovleva 1997 'Yellow' laccase of Panus tigrinus oxidizes non-phenolic substrates without electron-transfer mediators. FEBS Lett., 413: 446-448

Li, K. C., F. Xu and K. E. L. Eriksson 1999 Comparison of fungal laccases and redox mediators in oxidation of a nonphenolic lignin model compound. Appl. Environ. Microbiol., 65: 2654-2660

Lindeberg, G. and G. Holm 1952 Occurrence of tyrosinase and laccase in fruit bodies and mycelia of source Hymenomycetes. Physiol. Plant, 5: 100-114

Martins, L. O., C. M. Soares, M. M. Pereira, M. Teixeira, T. Costa, G. H. Jones and A. O. Henriques 2002 Molecular and biochemical characterization of a highly stable bacterial laccase that occurs as a structural component of the Bacillus subti- 
lis endospore coat. J. Biol. Chem., 277: 18849-18859

Mayer, A. M. and R. C. Staples 2002 Laccase: new functions for an old enzyme. Phytochem., 60: 551-65

Min, K. L., Y. H. Kim, Y. W. Kim, H. S. Jung and Y. C. Hah 2001 Characterization of a novel laccase produced by the woodrotting fungus Phellinus ribis. Arch. Biochem. Biophys., 392: $279-286$

Nakamura, K. and N. Go 2005 Function and molecular evolution of multicopper blue proteins. Cell. Mol. Life Sci. 62: 2050-2066

Niku-Paavola, M., E. Karhunen, P. Salola and V. Raunio 1988 Ligninolytic enzymes of the white rot fungus Phlebia radiata. Biochem. J., 254: 877-884

Couto Rodríguez, S. and J. L. Toca Herrera 2006 Industrial and biotechnological applications of laccases: A review. Biotechnol. Advances, 24: 500-513

Rogalski, J. and A. Leonowicz 2004 Laccase In: Concise Encyklopedia of Bioresource Technology (Ashok Pandy, ed.) Food Products Press, pp. 533-540, The Haworth Reference Press, New York

Rogalski, J., M. Wojtas-Wasilewska, R. Apalovic and A. Leonowicz 1990 Affinity chromatography as a rapid and convenient metod for purification of fungal laccases. Biotech. Bioeng., 37: $770-777$

Rogalski, J., T. Lundell, A. Leonowicz and A. Hatakka 1991 Production of laccase, lignin peroxidase and Manganesedependent peroxidase by various strains of Trametes versicolor depending on culture conditions. Acta Microbiol. Polon., 40: 221-234

Rogalski, J., A. Dawidowicz and A. Leonowicz 1990 Purification and immobilization of the inducible form of extracellular laccase of the fungus Trametes versicolor. Acta Biotechnol., 10: $261-269$

Rowiński, P., R. Bilewicz, M.J. Stebe and E. Rogalska 2004 Electrodes modified with monoolein cubic phases hosting laccases for the catalytic reduction of dioxygen. Anal. Chem., 76: 283

Sharma, P., Ć. R. Goel and Ć. N. Capalash 2007 Bacterial laccases. World J. Microbiol. Biotechnol., 23: 823-832
Shleev, S., A. Christenson, V. Serezenkov, D. Burbaev, A. I. Yaropolov, L. Gorton and T. Ruzgas 2005 Electrochemical redox transformations of $\mathrm{T} 1$ and $\mathrm{T} 2$ copper sites in native Trametes hirsuta laccase at gold electrode. Biochem J., 385: 745

Smirnov, S. A., O. V. Koroleva, V. P. Gavrilova, A. B. Belova and N.L. Klyachko 2001 Laccases from Basidiomycetes: physicochemical characteristics and substrate specificity towards methoxyphenolic compounds. Biochem., 66: 774-779

Smith, M. and C. F. Thurston 1997 Fungal laccases: role in delignification and possible industrial application. pp. 253-259. In: Messerschmidt, A. (ed.). Multicooper oxidases. World Sci., Singapore, New Jersey, London, Hong Kong

Solomon, E. I., U. M. Sundaram and T. E. Machonkin 1996 Multicopper oxidases and oxygenases. Chem. Rev., 96 2563-2605

Stoica, L., N. Dimcheva, Y. Ackermann, K. Karnicka, D. A. Guschin, P. J. Kulesza, J. Rogalski, D. Haltrich, R. Ludwig, L. Gorton and W. Schuhmann 2009 Membrane-less biofuel cell based on cellobiose dehydrogenase (anode)/laccase (cathode) wired via specific Os-redox polymers. J. Fuel Cell, 9: 53-62

Thurston, C. F. 1994 The structure and function of fungal laccases. Microbiol., 140: 19

Wahleithner, J. A., F. Xu, K. M. Brown, S. H. Brown, E. J. Golightly, T. Halkier, S. Kauppinen, A. Pederson and P. Schneider 1997 The identification and characterization of four laccases from the plant pathogenic fungus Rhizoctonia solani. Curr. Genet., 29: 395-403

Xu, F. 1999 Laccase. In: Flickinger, M. C. and S. W. Drew (eds.) Encyclopedia of bioprocess technology: fermentation, biocatalyses, bioseparation. pp. 1545-1554. Wiley \& Sons, New York

Yaropolov, A. I., O. V. Skorobogat'ko, S. S. Vartanov and S. D. Varfolomeyev 1994 Laccase-properties, catalytic mechanism, applicability. Appl. Biochem. Biotech., 49: 257-279

Zouari, N., J. L. Romette and D. Thomas 1987 Purification and properties of two laccase isoenzymes produced by Botrytis cinerea. Appl. Biochem. Biotechnol., 15: 213-225 